\title{
Enhancing Ecoliteracy through Traditional Ecological Knowledge in Proverbs
}

\author{
GoWoon Kim ${ }^{1}$, Rahul Teku Vaswani ${ }^{2}$, Wanmo Kang ${ }^{3}$, Miri Nam ${ }^{4}$ and Dowon Lee ${ }^{5, *}$ \\ 1 Asian Institute for Energy, Environment and Sustainability, Seoul National University, Seoul 08826, Korea; \\ agneskim@snu.ac.kr \\ 2 United Nations Economic and Social Commission for Asia and the Pacific, Rajadamnoen Nok, Bangkok \\ 10200, Thailand; ekashiana@yahoo.com \\ 3 Research Institute of Agriculture and Life Sciences, Seoul National University, Gwanak-ro 1, Gwanak-gu, \\ Seoul 08826, Korea; kangwanmo@gmail.com \\ 4 Interdisciplinary Program in Environmental Education Graduate School, Seoul National University, \\ Seoul 08826, Korea; miri-06-07@hanmail.net \\ 5 Graduate School of Environmental Studies, Seoul National University, Seoul 08826, Korea \\ * Correspondence: leedw@snu.ac.kr; Tel.: +82-288-05650
}

Received: 2 May 2017; Accepted: 29 June 2017; Published: 6 July 2017

\begin{abstract}
Proverbs can be regarded as pithy axioms of traditional ecological knowledge (TEK), which can be useful for sustainability education. By using an exploratory sequential mixed method, we analyzed TEK and ecoliteracy components embedded in rain- and tree-related Korean traditional proverbs, and further conducted a survey of university students to gauge their knowledge of the proverbs and draw correlations with their ecoliteracy. We classified 173 rain- and 117 tree-related traditional Korean proverbs and found that most of these were related to factual observations, such as ecological characteristics of tree species and the prediction of rainfall, which indicated people's understanding of ecological processes and patterns. We also found that students tended to provide correct answers for questions related to TEK-based worldviews, ethics and values, which are important components of ecoliteracy, thereby indicating the usefulness of proverbs in delivering TEK-based worldviews, ethics, and values. Overall, our study reasons that the learning of TEK-related traditional proverbs can be meaningful for enhancing ecoliteracy among urban youth, particularly when this learning is complemented with field-based observational learning within integrated approaches for sustainability education.
\end{abstract}

Keywords: ecoliteracy; ecology education; proverb; sustainability education; traditional ecological knowledge; Korea

\section{Introduction}

An integral aspect of sustainability is "the need to place (the) understanding of environmental concerns within a social, economic, and political context" [1]. For raising socio-cultural awareness of modern environmental challenges, "ecological literacy" or "ecoliteracy" is gaining prominence within pedagogical, ecological, and political discourses as an effective approach [2-9]. In this regard, ecologists and environmentalists are developing various methods and experiments for enhancing ecoliteracy [4], including through human-centered and place-based modes [10], practices based on large public datasets [11], service learning and citizen science [6], political tactics [2], and technological methods [12].

Ecological awareness has also been inherent to human societies since their inception, as humans have intrinsically depended on the resources and services of their immediate ecosystems [2,13]. Traditional or pre-industrialized societies developed a comprehensive knowledge of natural resources 
management and refined it over generations in response to social-ecological challenges and human needs. Cultural and ecological scientists recognize the accumulated ecological knowledge, practices, and beliefs held by traditional communities, and transmitted inter-generationally through proverbs, songs, folklore, stories, and myths, as "traditional ecological knowledge" (TEK) [14-16]. In our study, we adhere to the comprehensive definition of ecoliteracy as the ability of individuals to identify names, uses, and related stories of living organisms and natural phenomena in their local ecosystems based on their TEK $[2,13]$. This also relates to an individual's scientific habits of mind in relation to ecological issues, and the appreciation for ecological connectivity and social-ecological linkages [3]. Based on this definition, it is clear that the oral transfer of TEK has a pivotal role in perpetuating ecoliteracy and sustainable resource management practices over generations $[2,13]$.

The transfer of TEK through cultural means, however, is being weakened by various modern processes: urbanization, dissolution of traditional societies, the Westernization of learning systems, and the commodification of natural resources [2]. To attain widespread ecoliteracy, ecologists require innovative, public-friendly approaches that can maintain and apply traditional ecological wisdom within cultural contexts $[3,4,10,13]$. Traditional proverbs are an oral medium of TEK transfer, which can be an easily comprehensible and culturally friendly means for inculcating ecoliteracy among modern citizens, particularly among urban residents. Literary research on proverbs has shown that they serve not only as valuable repositories of folk wisdom that provide "succinct descriptions of events" and describe societal "concerns with morality" [17], but also as representations of the worldviews of communities embedded within their natural resource systems [18]. In addition, proverbs contain the knowledge, concerns, ethics, and spirituality of local communities, which can be reflected and integrated in local conservation initiatives [18].

Therefore, we hypothesize that proverbs can serve as pithy axioms of TEK and can be a useful medium for sustainability education. What is needed then is an inquiry into the TEK-related and ecoliteracy components inherent in proverbs, and analysis of their efficacy in communicating ecological wisdom within integrated educational approaches.

Thus, this study first examined what types of knowledge and wisdom are embedded in traditional proverbs. Subsequently, we gauged students' knowledge of the proverbs and analyzed possible factors that might affect their knowledge of TEK-related proverbs. To these ends, we used exploratory sequential mixed methods and conducted the analysis in two phases. In the first phase, we qualitatively examined Korean traditional proverbs for their embedded TEK-related and ecoliteracy-related contents. In the second, quantitative phase, we conducted a survey of university students to identify the factors related to their ecoliteracy and to determine correlations with their knowledge of proverbs. Through this study, we hope to suggest a novel way of using common repositories of folk wisdom, such as TEK-related proverbs, for cultivating ecoliteracy by facilitating a greater comprehension of the social-ecological dimensions of living.

\section{Materials and Methods}

We adapted an exploratory sequential methodological framework proposed by Creswell and Clark [19] to examine proverbs and gain understanding on the factors correlated with students' knowledge of proverbs in two phases. In the first phase, we used a qualitative, directed content analysis method to explore TEK-related and ecoliteracy-related contents in traditional Korean proverbs. In the subsequent, quantitative phase, we surveyed 70 university students at Seoul National University in South Korea to explore the possible factors that influence the ecoliteracy of urban youth as indicated by their TEK-related knowledge. The quantitative phase of the study was supplementary, in that it helped to understand students' ecological knowledge and different experiences in relation to proverbs, thereby examining the usefulness of proverbs in enhancing ecoliteracy in educational settings in South Korea. In our Supplementary Materials, we also provided both Korean and English translations for the proverbs mentioned in this paper. 


\subsection{Collection of Rain- and Tree-Related Proverbs}

As in other industrialized nations, pre-industrial South Korea was predominantly agricultural. Koreans depended on their natural environment and developed well-adapted methods for natural resources management, as illustrated in the traditional Korean proverb, "Farmers are fundamental to the world." Korean traditional societies established complex agroforestry systems within watersheds, so as to use the watershed boundaries to optimally harvest rainwater and prevent excess wind and overflow of water. Several pioneering studies of Korean TEK, as presented in the multi-volume Korean Traditional Ecology [20,21], have discussed the importance of Korean traditional water harvesting and agroforestry practices to the sustainability of Korean societies. Studies have also shown that Koreans developed their TEK in relation to rainwater management at various scales from individual households to watersheds [22,23]. This TEK is receiving much scientific attention, as the frequency of severe drought in Korea has been increasing in recent years [22,24,25]. Furthermore, several Korean TEK-related studies have discussed the use of trees in traditional village landscape management, such as the various social-ecological functions of cultivated village groves [26-28]. Hence, it can be surmised that there is a great wealth of Korean TEK related to rain and trees-understandably, the most important natural resources in Korean traditional societies-within traditional proverbs.

Therefore, based on our literature review of Korean TEK and relevant adaptive management practices, among the various ecological elements that can reveal TEK in Korean traditional proverbs, we deliberately focused on rain and trees. We collected rain- and tree-related proverbs from three volumes of the most comprehensive Korean proverb dictionary [29]. In addition, we included questions related to trees in the quantitative ethnobotanical interviews of student to assess the students' knowledge of local plants in relation to their understanding of TEK, based on previous literature on ecoliteracy [2].

\subsection{Qualitative Exploration of Korean TEK and Key Components of Ecoliteracy Embedded in Proverbs}

After collecting proverbs related to rain and trees, we thematically classified the collected proverbs using computer-assisted qualitative data analysis software MAXQDA 11 (VERBI Software, Berlin, Germany). We used a directed content analysis approach, from the three representative content analysis approaches: conventional, directed, and summative [30]. The codes we used for our analysis were guided by previous literature on the six groups of TEK [31] and three ecoliteracy components [3,6,32].

The six groups of TEK, as given by Houde [31], are: (1) factual observations; (2) management systems; (3) past and current uses of the environment; (4) ethics and values; (5) vector for cultural identity; and (6) cosmology. For the credibility of the qualitative classification process, we further developed the criteria for classification of the proverbs. For example, we classified proverbs that deliver knowledge in relation to ecological principles and characteristics into the first group of TEK, i.e., factual observations. Similarly, we used the following classifications for the other groups of TEK: farming practices, seasonal knowledge, and landscape and environmental management for the second group of TEK; the similarity or differences between two time periods in relation to the resources for the third group; ethical and moral issues or teachings in relation to rain and trees for the fourth group; Korean traditional and cultural elements for the fifth group; and people's beliefs and worldviews in relation to rain and trees for the sixth group.

We also further classified the proverbs as per the three key ecoliteracy components suggested by the existing literature on ecoliteracy: (1) scientific understanding of environmental or ecological processes and patterns; (2) grasp of ecological connectivity; and (3) appreciation for the connections between ecological and social systems [3,6,32]. In our study, the first ecoliteracy component indicates scientific knowledge of ecological processes and patterns at a relatively small scale such as a tree species or community. The second ecoliteracy component, i.e., the grasp of ecological connectivity, refers to scientific knowledge of ecological processes and patterns at the landscape-level. The third ecoliteracy component indicates an understanding of the tightly coupled human-nature systems and of the feedbacks between the two systems. In our preliminary classification of the proverbs according to these three components of ecoliteracy, we found that it was difficult to identify proverbs directly related 
to an understanding of social-ecological linkages. Subsequently, to further identify social-ecological and cultural components embedded in the tree- and rain-related proverbs, we conducted a frequency analysis of one or two keywords such as species of trees and animals.

\subsection{Quantitative Survey}

To comprehend the usefulness of proverbs in communicating ecological knowledge, we analyzed the factors that influence the ecoliteracy of urban youth as indicated by their knowledge of Korean TEK-related proverbs. To this end, we surveyed 70 students at Seoul National University for the following: (1) students' frequency of visits to the countryside and to interactions with grandparents, both of which can be avenues of TEK-related knowledge in Korea; (2) students' knowledge of proverbs and the sources of their proverb-related knowledge; and (3) students' knowledge of TEK in resource-related proverbs, particularly their knowledge of local plants and cultural landscape elements, and the meanings of selected proverbs.

First, we provided participants with a set of multiple-choice questions by adapting the list of questions from Pilgrim, Smith and Pretty [2]. The first set of questions were the following: (1) frequency of the student's countryside visits; (2) experiences living in the countryside; (3) time spent by the student with her/his family (including grandparents); (4) household income; (5) educational background; (6) whether the student's academic major was related to ecology or environmental science; and (7) whether the student had taken any ecology- or environment-related classes. This set of questions was aimed at gathering a student's general background and finding relations with possible factors affecting their knowledge of proverbs.

Our survey also included a set of multiple-choice questions regarding the student's knowledge of TEK-proverbs. For this, we asked how many proverbs the student was familiar with and what the primary source of knowledge of proverbs was. However, as each student may have a different notion about "knowing" proverbs, we also included a set of 10 multiple-choice questions as a quantitative ethnobotanical test. Drawing from similarly conducted studies, for the ethnobotanical test we used flashcards with tree species $[2,33]$. We first provided 10 tree-related proverbs that belonged to the first group of TEK, based on our first phase of research, as most of the proverbs from the first group were found to contain knowledge in relation to ecological characteristics of tree species. The tree species were carefully selected to reflect the result of our frequency analysis of tree species in proverbs. Then, we showed each student 10 flashcards on the screen and the student was required to match the pictures with the proverbs. Each question was equivalent to 1 score.

Furthermore, we asked questions to assess the students' recognition of Korean traditional village landscape elements that frequently appear in proverbs, and a set of 10 short-answer questions on the meanings of proverbs. The proverbs in the 10 short-answer questions were chosen based on our qualitative categorization of proverbs as per the six groups of TEK (Table 1).

We used SPSS 22.0 (IBM 2013) to perform nonparametric statistical tests in examining non-normally distributed data, to obtain more conservative results. We used the Mann-Whitney U test to investigate the influences of students' experiences in ecological classes on their knowledge of proverbs. We conducted Spearman's rank correlations to test the associations between students' knowledge of proverbs and the following factors: (1) the frequency of visits to the countryside; (2) time spent by the student with her/his family (including grandparents); (3) household income; and (4) college major. We also performed Spearman's rank correlation to see whether the number of the proverbs each student claims to be familiar with is parallel to the result of the questions on the meanings of TEK-related proverbs. 
Table 1. Selection of proverbs for 10 short-answer questions as per six groups of traditional ecological knowledge (TEK).

\begin{tabular}{lc}
\hline \multicolumn{1}{c}{ Proverb } & Six Groups of TEK \\
\hline If the pine shoot grows tall, comes a bumper year. & Factual observations \\
Pine tree protects the field alone. & Factual observations \\
Straight personality like a bamboo tree. & Factual observations \\
Ginkgoes should stand face to face to bear fruits. & Factual observations \\
Even trees get sick for three years when transplanted to another place. & Management systems \\
When the mountain cries the field smiles, and when the field cries the mountain smiles. & Management systems \\
If a bird on a persimmon tree is unseen, it's late to prepare a rice seed plot. & Management systems \\
If a big shade tree of a village is cut, the village will be devastated. & Ethics and values \\
It is said that after giving birth to a baby girl, one should plant a paulownia tree. & Vector for cultural identity \\
A mountain god will bless you if you save firewood. & Cosmology \\
\hline
\end{tabular}

\section{Results}

We found that rain- and tree-related proverbs account for about five percent of the documented Korean proverbs, as we collected 319 rain-related and 166 tree-related proverbs from the approximately 10,000 proverbs listed in the three-volume reference. After collecting, we excluded proverbs that had similar or metaphorical meanings. As a result, we shortlisted 173 rain- and 117 tree-related proverbs that we thematically classified into the six groups of TEK and the three components of ecoliteracy. No proverb was classified in more than one group of TEK.

\subsection{Korean TEK and Key Components of Ecoliteracy Embedded in Proverbs}

Most of the rain-related proverbs (96\%) and tree-related ones (77\%) belonged to the first group of TEK-i.e., factual observation. As these proverbs were often based on scientific understanding of ecological processes and patterns, this result facilitated the classification of the proverbs as per the three components of ecoliteracy. Some proverbs belonging to the second group of TEK showed both first and second components of ecoliteracy: scientific understanding of ecological processes and patterns, as well as a grasp of ecological connectivity. In addition, the proverbs that were classified as the sixth group of TEK were based on people's understanding of the connection between ecological and social systems. The frequency across the six TEK groups and the three ecoliteracy components is summarized in Tables 2 and 3. Also, an example of the classification of the proverbs with interpretations of each proverb is shown in Table 4. More explanations and details of the results are presented in the Discussion section.

Table 2. Frequency of proverbs as per six groups of TEK.

\begin{tabular}{lcc}
\hline \multicolumn{1}{c}{ Six Groups of TEK } & Frequency of Rain-Related Proverbs & Frequency of Tree-Related Proverbs \\
\hline Factual observations & $96 \%$ & $77 \%$ \\
Management systems & $2 \%$ & $7 \%$ \\
Past and current uses of the environment & $0 \%$ & $0 \%$ \\
Ethics and values & $1 \%$ & $4 \%$ \\
Vector for cultural identity & $0 \%$ & $11 \%$ \\
Cosmology & $1 \%$ & $1 \%$ \\
\hline
\end{tabular}

Table 3. Frequency of proverbs as per ecoliteracy components.

\begin{tabular}{lcc}
\hline \multicolumn{1}{c}{ Three Ecoliteracy Components } & Frequency of Rain-Related Proverbs & Frequency of Tree-Related Proverbs \\
\hline Scientific understanding of environmental & $61 \%$ & $65 \%$ \\
or ecological processes and patterns & $24 \%$ & $8 \%$ \\
Grasp of ecological connectivity & $14 \%$ & $17 \%$ \\
Appreciation for the connections between & $1 \%$ & $10 \%$ \\
ecological and social systems & & \\
(Proverbs with no specific & & \\
\hline
\end{tabular}


Table 4. Classification criteria of proverbs and examples.

\begin{tabular}{|c|c|c|c|}
\hline Six Groups of TEK [31] & Proverbs & Interpretation of Proverbs & Ecoliteracy Components [3] \\
\hline \multirow{4}{*}{ Factual observations } & If there are many trees on the island, there are many fishes. & $\begin{array}{l}\text { The existence of many trees provides a good habitat for fishes. In } \\
\text { Korea, there are a number of groves for fish breeding as a type of } \\
\text { traditional adaptive management. }\end{array}$ & \multirow{6}{*}{$\begin{array}{l}\text { Scientific understanding of environmental } \\
\text { or ecological patterns and processes }\end{array}$} \\
\hline & If the pine shoot grows tall, comes a bumper year. & $\begin{array}{l}\text { Tall pine shoots indicate enough spring rain, thus a good } \\
\text { agricultural harvest is expected. }\end{array}$ & \\
\hline & $\begin{array}{l}\text { Trees don't benefit from big trees (while people benefit from } \\
\text { big people). }\end{array}$ & $\begin{array}{l}\text { Big trees require more nutrients and tend to block the sunlight } \\
\text { from small trees. }\end{array}$ & \\
\hline & If clouds strangle a mountain's neck, it will rain soon. & $\begin{array}{l}\text { Clouds (or fogs) hanging around the middle of a mountain } \\
\text { indicate that the area is under low atmospheric pressure, thus rain } \\
\text { is expected. }\end{array}$ & \\
\hline \multirow{3}{*}{ Management systems } & $\begin{array}{l}\text { Even trees get sick for three years when transplanted to } \\
\text { another place. }\end{array}$ & $\begin{array}{l}\text { It takes a time for even a tree to settle in a new environment, } \\
\text { particularly for its root system. }\end{array}$ & \\
\hline & The ground dries when Chubun has passed. & After Chubun, the weather starts to improve and become drier. & \\
\hline & $\begin{array}{l}\text { When the mountain cries the field smiles, and when the field } \\
\text { cries the mountain smiles. }\end{array}$ & $\begin{array}{l}\text { When rainfall is high, it can lead to a small landslide or great } \\
\text { runoff, which can bring rich nutrients for the plants in the fields. }\end{array}$ & Ecological connectivity \\
\hline $\begin{array}{l}\text { Past and current uses of the } \\
\text { environment }\end{array}$ & None & & \\
\hline Ethics and values & When cutting one tree, plant ten trees. & $\begin{array}{l}\text { One should think about the sustainability of forests, when } \\
\text { cutting trees. }\end{array}$ & \multirow{4}{*}{$\begin{array}{l}\text { An appreciation for the connection } \\
\text { between ecological and social systems. }\end{array}$} \\
\hline \multirow{4}{*}{ Vector for cultural identity } & Peach tree bats for the ghosts. & $\begin{array}{l}\text { Peach is often considered mysterious and numinous, and peach } \\
\text { trees are believed to have the power to expel ghosts. For this } \\
\text { reason, peach trees are not planted in a common household. }\end{array}$ & \\
\hline & Housewives first sense the rain. & $\begin{array}{l}\text { It is women who first notice the conditions for rainfall when they } \\
\text { have difficulty lighting a furnace due to the low atmospheric } \\
\text { pressure preceding rain. }\end{array}$ & \\
\hline & Housewives become generous when it rains in spring. & $\begin{array}{l}\text { Spring rain indicates a good agricultural harvest for the year, thus } \\
\text { housewives may share grains and crops. }\end{array}$ & \\
\hline & Ants distract a shade tree. & A shade tree is too grand to be affected by ants. & No ecoliteracy component \\
\hline Cosmology & The mountain god gives blessing when you conserve wood. & A person who conserves natural resources is considered good. & $\begin{array}{l}\text { Appreciation for the connections between } \\
\text { ecological and social systems }\end{array}$ \\
\hline
\end{tabular}


Through the keyword analysis of the rain-related proverbs, we found that the prediction of rain is a major theme; these proverbs are often associated with animal behavior and other natural phenomena (Table 5), or with seasonal knowledge of the farmer's traditional lunisolar calendar used in China and Korea, which comprises 24 seasonal divisions. The proverbs related to animal behavior and rain prediction also indicate the first component of ecoliteracy shown by traditional peoples, i.e., the habit of scientifically understanding environmental patterns. In addition, the rain-related proverbs associated with the 24 seasonal divisions show that much of Korean TEK in resource-related proverbs is closely related with people's seasonal knowledge and adaptive management practices in different weather conditions, as shown in Table 6. For the purpose of credibility, the interpretations of each proverb are also provided based on a local reference to 24 seasonal divisions [34].

Table 5. Rain-related proverbs associated with animal behavior and natural phenomena.

\begin{tabular}{|c|c|}
\hline Theme & Proverb \\
\hline Animal behavior & $\begin{array}{c}\text { It will rain if ants move in a line. } \\
\text { It will rain if ants cross a road. } \\
\text { It will rain if green frogs sing. } \\
\text { It will rain if swallows fly near the ground. } \\
\text { It will rain if seagulls fly low. } \\
\text { It will rain if a group of spiders passes by during a drought. } \\
\text { It will stop raining when spiders start spinning their webs. } \\
\text { It will rain if cats get worked up. } \\
\text { It will rain if bells sound clear. }\end{array}$ \\
\hline Natural phenomena & $\begin{array}{l}\text { It will rain if there are bubbles in ponds, lakes, and streams. } \\
\text { It will rain soon if wind blows from the south. } \\
\text { It will rain if there is a ring around the sun and the moon. } \\
\text { It will rain if smoke does not go outside (and stays inside the house). } \\
\text { It will rain heavily if there is thunder in the morning. }\end{array}$ \\
\hline
\end{tabular}

Table 6. Selected rain-related proverbs associated with traditional seasonal knowledge.

\begin{tabular}{llll}
\hline Four Seasons & \multicolumn{1}{c}{ Seasonal Division } & \multicolumn{1}{c}{ Proverb } & \multicolumn{1}{c}{ Meaning } \\
\hline & $\begin{array}{l}\text { Ipchun, } \\
\text { Start of spring (either February } \\
\text { 3rd or 4th in lunar calendar) }\end{array}$ & $\begin{array}{l}\text { The stick buried in Ipchun } \\
\text { snows. }\end{array}$ & $\begin{array}{l}\text { It may still snow much at the } \\
\text { beginning of spring. }\end{array}$ \\
\cline { 2 - 4 } $\begin{array}{l}\text { Usu, } \\
\text { Rain water (either February 18th } \\
\text { or 19th in lunar calendar) }\end{array}$ & $\begin{array}{l}\text { Heavy Usu rains bring a } \\
\text { plentiful harvest. }\end{array}$ & $\begin{array}{l}\text { High rainfall which thaws the } \\
\text { ground on Usu will guarantee a } \\
\text { good planting season. }\end{array}$ \\
\cline { 2 - 3 } $\begin{array}{l}\text { Chunbun, } \\
\text { Vernal equinox (either March 20th } \\
\text { or 21st in lunar calendar) }\end{array}$ & $\begin{array}{l}\text { West wind on Chunbun will } \\
\text { bring a bad barley harvest. }\end{array}$ & $\begin{array}{l}\text { The west wind in mid to late } \\
\text { March means that a drought will } \\
\text { occur and ruin the barley harvest. }\end{array}$ \\
\cline { 2 - 4 } $\begin{array}{l}\text { Cheong-myeong, } \\
\text { Clear and bright (either April 4th } \\
\text { or 5th in lunar calendar) }\end{array}$ & $\begin{array}{l}\text { South wind on } \\
\text { Cheong-myeong brings a } \\
\text { good harvest. }\end{array}$ & $\begin{array}{l}\text { The south wind with rain around } \\
\text { April 5th means plentiful water } \\
\text { and a good planting season. }\end{array}$ \\
\hline $\begin{array}{l}\text { Gok-u, } \\
\text { Grain rain (either April 20th or } \\
\text { 21st in lunar calendar) }\end{array}$ & $\begin{array}{l}\text { A wet Gok- } u \text { makes a } \\
\text { plentiful harvest, and a dry } \\
\text { one brings a bad harvest. }\end{array}$ & $\begin{array}{l}\text { The sixth seasonal division of 24, } \\
\text { Gok- } u \text { falls around April 20th. A } \\
\text { good harvest requires good rains } \\
\text { around Gok- } u \text {. }\end{array}$ \\
\hline
\end{tabular}


Table 6. Cont.

\begin{tabular}{|c|c|c|c|}
\hline Four Seasons & Seasonal Division & Proverb & Meaning \\
\hline \multirow{10}{*}{ Summer } & $\begin{array}{l}\text { Mangjong, } \\
\text { The barley harvest season (either } \\
\text { June } 5 \text { th or } 6 \text { th in lunar calendar) }\end{array}$ & $\begin{array}{l}\text { Mangjong droughts are like } \\
\text { your debt collectors. }\end{array}$ & $\begin{array}{l}\text { Mangjong falls around June } 6 \text { th. } \\
\text { The proverb means this time of } \\
\text { year is always dry. }\end{array}$ \\
\hline & \multirow{2}{*}{$\begin{array}{l}\text { Haji, } \\
\text { Summer solstice (either June 21st } \\
\text { or } 22 \text { nd in lunar calendar) }\end{array}$} & $\begin{array}{l}\text { After Haji, clouds are a } \\
\text { suggestion of rain. }\end{array}$ & $\begin{array}{l}\text { Every cloud formed in the rainy } \\
\text { season drops rain. }\end{array}$ \\
\hline & & Wet feet after Haji. & $\begin{array}{l}\text { After Haji, in the rainy season, } \\
\text { farmers are busy managing the } \\
\text { water from the rains. }\end{array}$ \\
\hline & $\begin{array}{l}\text { Soseo, } \\
\text { Minor heat (either July } 6 \text { th or } 7 \text { th } \\
\text { lunar calendar) }\end{array}$ & $\begin{array}{l}\text { Check the Soseo rains before } \\
\text { planting the Cheonbong-jigi } \\
\text { paddies. }\end{array}$ & $\begin{array}{l}\text { Cheonbong-jigi paddies are rice } \\
\text { paddies that solely rely on } \\
\text { rainwater. This means that } \\
\text { although only water from the } \\
\text { rainy season around Soseo is } \\
\text { available for rice planting, it is still } \\
\text { better than planting other grains. }\end{array}$ \\
\hline & \multirow{2}{*}{$\begin{array}{l}\text { Ipchu, } \\
\text { Start of fall (either August 7th or } \\
\text { 8th in lunar calendar) }\end{array}$} & $\begin{array}{l}\text { Rainfall on Ipchu is essential } \\
\text { for a good vegetable } \\
\text { harvest. }\end{array}$ & $\begin{array}{l}\text { Ipchu is the time when fall season } \\
\text { vegetable seeds are sown. } \\
\text { Adequate rainfall makes for a } \\
\text { good vegetable harvest. }\end{array}$ \\
\hline & & $\begin{array}{l}\text { Little Ipchu rain brings a } \\
\text { good harvest, whereas } \\
\text { heavy rains harm the rice. }\end{array}$ & $\begin{array}{l}\text { Rice grows rapidly around Ipchu; } \\
\text { adequate rainfall during this } \\
\text { period helps the crop, but too } \\
\text { much is harmful. }\end{array}$ \\
\hline & $\begin{array}{l}\text { Cheoseo, } \\
\text { Subsidence of heat (either August } \\
\text { 22nd or 23rd in lunar calendar) }\end{array}$ & $\begin{array}{l}\text { Cheoseo rains mean less } \\
\text { grain in the pot. }\end{array}$ & $\begin{array}{l}\text { Rains in late August, when Cheoseo } \\
\text { falls, make the rice flowers wilt } \\
\text { and greatly reduce the harvest. }\end{array}$ \\
\hline & \multirow{2}{*}{$\begin{array}{l}\text { Baekro, } \\
\text { White dew (either September } 7 \text { th } \\
\text { or 8th in lunar calendar) }\end{array}$} & $\begin{array}{l}\text { The summer rains leave } \\
\text { with Baekro. }\end{array}$ & $\begin{array}{l}\text { The rains stop by Baekro, in } \\
\text { early September. }\end{array}$ \\
\hline & & $\begin{array}{l}\text { Baekro rains mean a } \\
\text { bad harvest. }\end{array}$ & $\begin{array}{l}\text { On Baekro, in early September, } \\
\text { grains need good sunlight for a } \\
\text { good harvest. Rains on Baekro } \\
\text { therefore mean a poor harvest. }\end{array}$ \\
\hline & $\begin{array}{l}\text { Chubun, } \\
\text { Autumnal equinox (either } \\
\text { September 22nd or 23rd in } \\
\text { lunar calendar) }\end{array}$ & $\begin{array}{l}\text { The ground dries when } \\
\text { Chubun has passed. }\end{array}$ & $\begin{array}{l}\text { After Chubun, the weather starts to } \\
\text { improve and becomes drier. }\end{array}$ \\
\hline Winter & $\begin{array}{l}\text { Dongji } \\
\text { Winter solstice (either December } \\
\text { 21st or 22nd in lunar calendar) }\end{array}$ & $\begin{array}{l}\text { Heavy snowfall on Dongji } \\
\text { brings heavy rainfall in May } \\
\text { and June. }\end{array}$ & $\begin{array}{l}\text { Heavy snowfall on the winter } \\
\text { solstice means a good harvest. It is } \\
\text { the way of nature that a lot of } \\
\text { snowfall in the winter means a lot } \\
\text { of rainfall the following year, and } \\
\text { a higher likelihood of a } \\
\text { good harvest. }\end{array}$ \\
\hline
\end{tabular}

Through the keyword analysis of the tree-related proverbs, we found that the Korean red pine (Pinus densiflora) is the most frequently mentioned tree (Table 7). This finding is similar to that reported by Korea's National Institute of Forest Science in their frequency analysis of tree species in Korean forest-related legends with the frequency of Korean red pine being 37.1\% (Table 7) [35].

In addition, in the attempt to further find social-ecological linkages in the proverbs, we found that several proverbs contain the phrase "a shade tree," which is an important cultural landscape element in traditional Korean villages. Examples are: (1) "Ants distract a shade tree," (2) "Like a big ant shaking a shade tree," and (3) "With deep love, a husband and a wife will sleep under a shade tree 
if they have no house, will beg for rice if they have no rice, and will eat with their hands if they have no spoon."

Table 7. Frequency of tree species mentioned in tree-related proverbs and in Korean traditional legends [35].

\begin{tabular}{|c|c|c|c|c|c|}
\hline \multicolumn{3}{|c|}{ Tree-Related Proverbs } & \multicolumn{3}{|c|}{ Korean Traditional Legends } \\
\hline Common & Scientific Name & $\begin{array}{c}\text { Frequency } \\
(\%)\end{array}$ & Common Name & Scientific Name & $\begin{array}{c}\text { Frequency } \\
(\%)\end{array}$ \\
\hline Korean red pine & Pinus densiflora & 27.4 & Korean red pine & Pinus densiflora & 37.1 \\
\hline Korean pine & Pinus koraiensis & 8.1 & Ginkgo & Ginkgo biloba & 20.0 \\
\hline Persimmon & Diospyros kaki & 8.1 & Camphor tree & Cinnamomum camphora & 5.7 \\
\hline Willow & Salix spp. & 6.5 & Elm & Ulmus davidiana & 5.7 \\
\hline Bamboo & Phyllostachys spp. & 6.5 & Oak & Quercus spp. & 5.7 \\
\hline White mulberry & Morus alba & 4.8 & Chinese pea tree & Caragana sinica & 2.9 \\
\hline Peach tree & Prunus persica & 4.8 & Japanese zelkova & Zelkova serrata & 2.9 \\
\hline Jujube & Zizyphus jujube & 4.8 & Birch & Betula spp. & 2.9 \\
\hline Ginkgo & Ginkgo biloba & 3.2 & Japanese chestnut & Castanea crenata & 2.9 \\
\hline Korean foxglove tree & Paulownia tomentosa & 3.2 & Korean foxglove tree & Paulownia tomentosa & 2.9 \\
\hline Birch & Betula spp. & 3.2 & Korean ginseng & Panax ginseng & 2.9 \\
\hline Katsura tree & Cercidiphyllum japonicum & 3.2 & Korean pine & Pinus koraiensis & 2.9 \\
\hline Japanese bladdernut & Staphylea bumalda & 3.2 & Manchurian fir & Abies holophylla & 2.9 \\
\hline Japanese alder & Alnus japonica & 1.6 & Pagoda tree & Styphnolobium japonicum & 2.9 \\
\hline Korean honey locust & Gleditsia koraiensis & 1.6 & & & \\
\hline Oak & Quercus spp. & 1.6 & & & \\
\hline Plum tree & Prunus salicina & 1.6 & & & \\
\hline Japanese zelkova & Zelkova serrata & 1.6 & & & \\
\hline Prickly castor oil tree & Kalopanax septemlobus & 1.6 & & & \\
\hline Tea tree & Camellia sinensis & 1.6 & & & \\
\hline Trifoliate orange & Citrus trifoliate & 1.6 & & & \\
\hline
\end{tabular}

\subsection{Results of the Survey}

Among the surveyed students, $94 \%$ were urban citizens and had an interest in taking sustainability courses. The analysis of the survey data showed that the students who had taken ecological classes performed better in response to the questions on the meaning of proverbs, than those students who had not taken ecological classes (Mann-Whitney U-test, $\mathrm{U}=431, p<0.05$ ). Also, those students who had spent more time with their grandparents tended to know more proverbs (Spearman's rho $=0.308$, $p<0.05)$. We found that there was no correlation between the time spent with grandparents and the experiences in taking ecological classes $(p>0.05)$. Other factors, such as frequency of visits to the countryside, household income, and college major, were not significantly correlated with the students' knowledge of proverbs $(p>0.05)$. Most students indicated their primary source of knowledge of proverbs as books (not related to students' educational curricula) (37\%), followed by formal educational curricula (31\%), family and relatives $(20 \%)$, television programs $(9 \%)$, and personal hobbies ( $3 \%$ ) (Figure 1). In addition, we asked the students whether they were aware of some traditional landscape elements such as traditional village groves and village ponds; less than $21 \%$ responded that they had only heard of them in their ecology and/or environmental classes.

In terms of the number of the proverbs known, $32 \%$ of the students answered that they were familiar with more than 30 proverbs, $26 \%$ of the students with more than 20 proverbs, $13 \%$ of the students with more than 40 proverbs, $13 \%$ of the students with more than 10 proverbs, $10 \%$ of the students with less than 10 proverbs, and the rest of the students $(8 \%)$ said that they were familiar with more than 50 proverbs. We found that the students who claimed to be familiar with a higher number of proverbs tended to provide right answers for the questions related to embedded meanings of the resource-related proverbs (Spearman's rho $=0.345, p<0.01$ ). The results of the ethnobotanical interview indicated that students are most familiar with three tree species: Korean red pine $(78.57 \%)$, bamboo $(75.51 \%)$, and gingko $(57.14 \%)$. Also, the results of short-answer questions indicated that students tended to provide most correct answers for questions related with worldviews $(92.86 \%)$ and with ethics and values $(67.14 \%)$, and the least correct answers for questions related with ecological factual observations (28.57\%) and with management systems (32.86\%). 


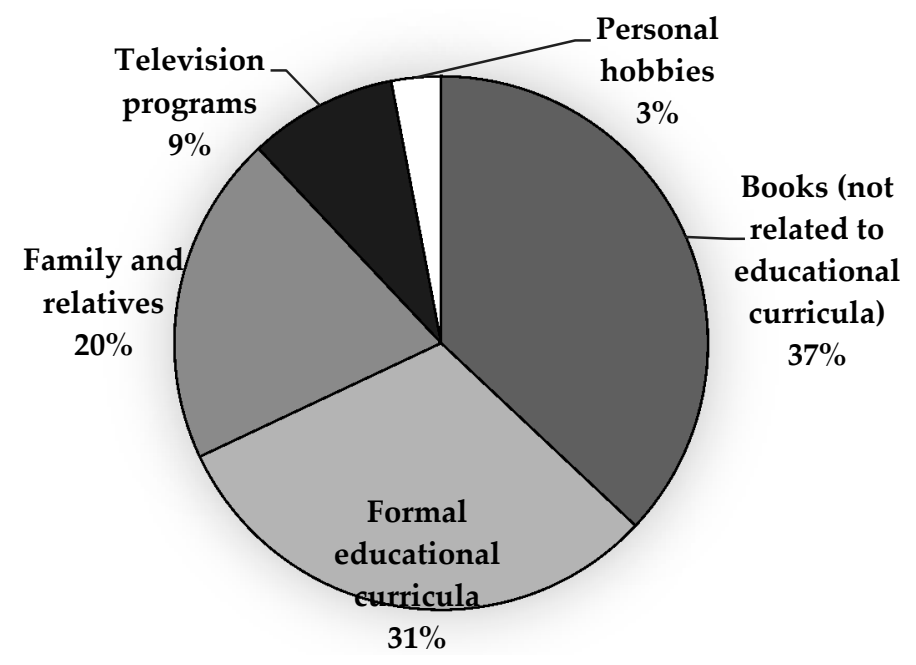

Figure 1. Survey results for students' primary source of knowledge of the proverbs.

\section{Discussion}

In this study, multiple methods were used to explore ecological knowledge and wisdom embedded in traditional proverbs, as well as factors in relation to current students' knowledge of proverbs to discuss the usefulness of proverbs for enhancing ecoliteracy. In this section, further implications of the major findings and limitations of our approach are discussed.

\subsection{TEK-Related Contents and Key Components of Ecoliteracy Found in Korean Proverbs}

Our qualitative examination of embedded TEK and ecoliteracy components in Korean proverbs shows that the first and second groups of TEK, i.e., factual observations and management systems, are closely related with the first components of ecoliteracy, i.e., scientific understanding of environmental and ecological patterns and processes. Similarly, the sixth group of the TEK, i.e., cosmology, is related with the third component of ecoliteracy, i.e., an appreciation of the linkages between ecological and social systems. This implies that the Korean TEK reflected in the resource-related proverbs shows the comprehensive characteristics of TEK, in that it is a complex of knowledge, practices, and beliefs [14]. In this regard, studies on ecoliteracy also state that the ultimate purpose of ecoliteracy is to influence persons to have integrated abilities of head, heart, hands, and spirit within their social-ecological environments $[5,36]$. Our study shows that traditional proverbs may be used as a means to deliver and develop such integrated aspects of ecoliteracy.

Both rain- and tree-related proverbs provide knowledge that can help in developing a conceptual framework of the agro-climatic conditions in Korea. In addition, we observed a higher frequency for rain-related proverbs than tree-related ones, and most rain-related proverbs indicate peoples' close observations of rain conditions in critical agricultural periods. This suggests that water was more likely a limiting factor for sustenance than wood in Korean traditional societies. Spring precipitation in Korea accounts for less than $20 \%$ of the total annual precipitation [26]; a spring drought can lead to precarious conditions for farmers, thus leading to a greater need for the Korean traditional people to closely observe and culturally encapsulate seasonal knowledge of ecological conditions related to spring rain in their proverbs. Such seasonal knowledge involves knowledge of the weather, seasonal cycles of living organisms, and the linkages with traditional culture and land uses, which has great potential to contribute to the current knowledge of natural resource management [37].

Korean traditional proverbs can be useful in cultivating one or more components of ecoliteracy in the Korean cultural and natural resource conditions. For example, "It will rain if ants cross a road" and "It will rain if green frogs sing" are traditional proverbs indicating Korean peoples' astute observations of natural phenomena and resource conditions-in this case, the availability of water. Another proverb, 
"Housewives first sense the rain," means that it is women who first notice the conditions for rainfall when they have difficulty lighting a furnace owing to the low atmospheric pressure preceding rain. Through these kinds of proverbs, it is possible to engage public citizens in describing, explaining, and predicting natural phenomena in Korea's particular cultural settings, which can inculcate scientific habits in relation to comprehending environmental issues of a given social-ecological system.

Several proverbs reveal deep notions of ecological connectivity, and of the interrelationship between ecological and social systems. "When the mountain cries the field smiles, and when the field cries the mountain smiles" is a proverb that indicates the typical topography and the interaction of landscape components of a traditional Korean village-i.e., situated within a watershed to secure access to water. Korean people traditionally built their villages according to the East Asian geomantic configuration of "back-mountain-front-water" (bae-san-im-su) because such topography would allow the residents to collect water easily [26]. In this configuration, a mountain protects the village from cold winter winds and harvests the humidity from the spring and summer winds; the village residences are settled on the gentle slope facing the mountain; the cultivated fields are in flatter land in the front of the residences; and, often, a river or stream flows in front of the fields. The mountain also serves as a natural forest refuge and as a source of spring or flowing water used for daily living. This proverb illustrates the contrasting effect of rainfall in such a landscape-when the rainfall is high, it may lead to a small landslide or great runoff, which can bring rich nutrients for the plants in the fields. This kind of proverb not only expresses ecological connectivity, but also provides culturally embedded ecological wisdom on desirable village landscape configuration. In addition, effective rainwater harvesting was important for social-ecological resilience, given the dry Korean spring season when seeding and transplanting are done, and the sometimes excessive monsoon rainfall [26,36,38].

Proverbs that mention "a shade tree" also relate to Korea's traditional ecological-cultural landscape. The shade tree can imply a village grove or forest. Village groves were planted, based on East Asian geomantic principles, to complement the village landscape [28] and served as a commons for social interaction and conducting spiritual rites, along with the village well or pond. Spiritual rites observed once or twice a year as part of village grove culture were an important part of the community identity. Village groves and their associated culture are now disappearing in South Korea because of urbanization. A number of vestigial village groves have been marked for restoration by Korean national and local governments, and have been used as places for community learning [22].

With regard to the frequency analysis for tree species in tree-related proverbs, it was found that Pinus densiflora is the most frequently mentioned species. P. densiflora is widely cultivated on the Korean Peninsula and has spiritual and cultural significance in Korean society; it represents fidelity and is mentioned in the South Korean national anthem. Thus, it is not surprising that $P$. densiflora is the most frequently mentioned species in Korean folklore [35]. While the frequency analysis shows that traditional proverbs may provide insights into social-ecological relationships, it also presents an irony regarding the weakening of traditional cultures and TEK with the process of urbanization.

In traditional Korean society, as recent as the Joseon Dynasty, forests were communally managed by a community-based, self-governing, organization called songgye [39]. As the songgye and its related TEK are disappearing due to urbanization and privatization of lands, modern Korean landscaping practices have begun to unduly favor $P$. densiflora. Urban landscapers now eagerly plant $P$. densiflora in most residential complexes by transporting adult trees from rural and mountainous areas (Figure 2).

The traditional proverb, "Even trees get sick for three years when transplanted to another place," illustrates ecological wisdom cautioning people on inappropriate ecological management practices. There is a distinction between knowing proverbs and correctly applying them, and this difference has been of great interest in folklore and anthropological studies [40]. The ultimate goal of using proverbs to enhance ecoliteracy should be to apply the TEK imminent in the proverbs to reach to ecologically and socially beneficial decisions; this, indeed, relies on the effective continuation and comprehension of TEK indicated in the proverbs. 


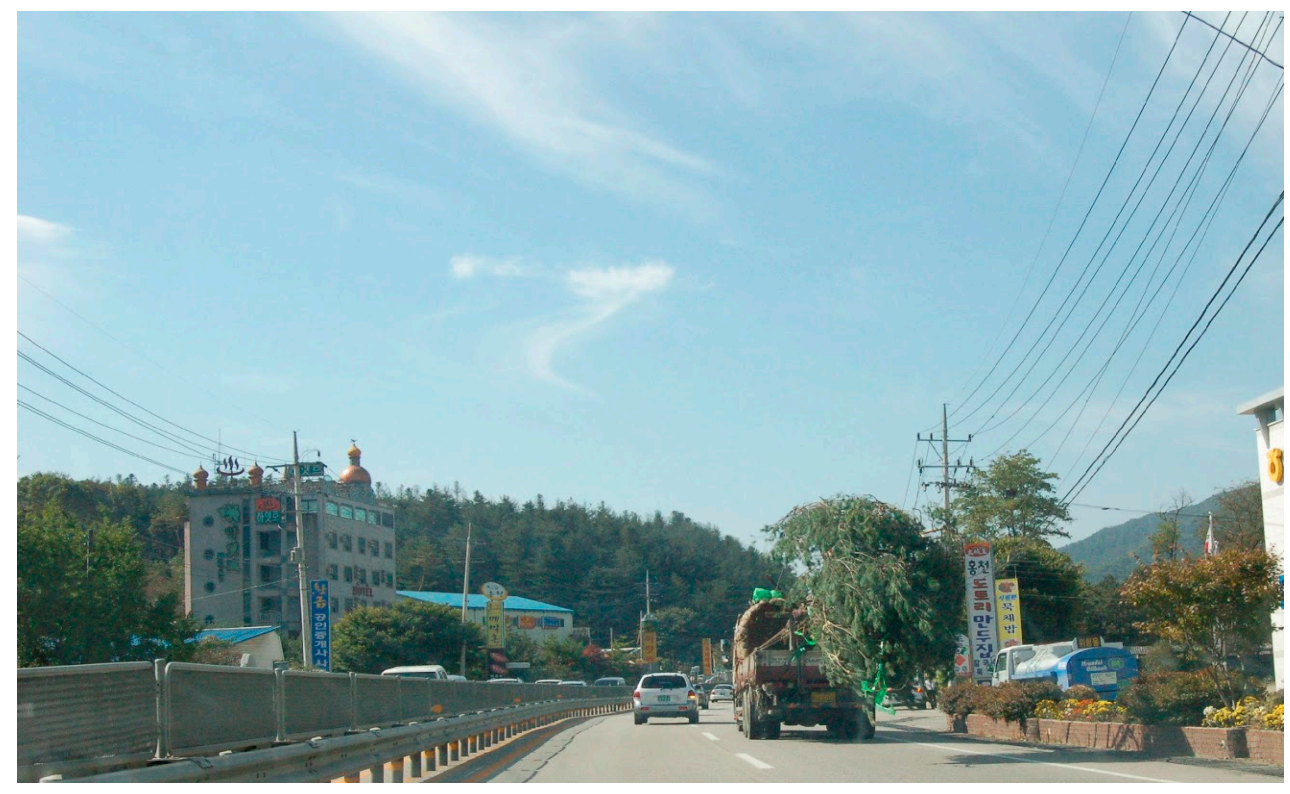

Figure 2. A scene of Pinus densiflora being transported from a rural area (captured by D. Lee in 2010).

\subsection{Potential Use of TEK Proverbs for Enhancing Ecoliteracy}

Previous literature on ecoliteracy claims that experiences of rural or countryside living, and acquiring knowledge from senior family members and community members are important factors of ecoliteracy [2]. Our survey results also show that spending time with grandparents may relate to a richer knowledge of proverbs. However, the survey results indicate that the university students acquire more of their knowledge of TEK-related proverbs from books and school than from their families, and time spent in the countryside is not a significant factor, indicating the growing importance of formal educational settings in TEK learning.

Grandparents can play an important role in transmitting cultural knowledge that benefits adolescents in their psychosocial development [41]. Recent studies have shown that youth with a good relationship with their grandparents tend to do better in school and have higher grades [42]. In family relation studies, it is known that spending time with grandparents can improve the individual's cognitive development [43]. Therefore, although the time spent with grandparents may not be the primary factor, in the case of the surveyed university students, for the learning of Korean TEK-related proverbs, it may indeed influence a student's ability to recognize and understand the proverbs mentioned in books or in formal educational curricula.

As nuclear families are increasingly becoming the norm in Korea-that is, Korean youth have fewer opportunities to live or interact with their grandparents-it is difficult to expect that TEK will primarily be transmitted orally over generations in urban environments without active intervention by ecologists and other educational specialists. In addition, in urban environments in industrialized countries such as South Korea, there is growing emphasis on instructional learning in groups of similar ages, rather than on participative and inquiry driven co-creative learning involving members of different generations as in traditional societies. We found that taking ecology- or environment-related classes influences the students' knowledge of proverbs. Thus, it can be purposeful to incorporate the study of traditional proverbs and their social-ecological meanings in the formal educational curricula.

Some proverbs, particularly those classified as the fourth and sixth groups of TEK, relate to matters of morality and cosmology that are based on an understanding of essential social-ecological linkages within the context of human dependence on natural resources. Successful conservation of indigenous or local social-ecological systems is often a result of people's TEK that guides them with spiritual connection to their local environments [44]. Interestingly, our survey results show that students tend to perform better for understanding the meanings of proverbs in relation to TEK-based 
ethics, values, and worldviews. Thus, proverbs are useful not only in delivering factual ecological knowledge and wisdom but also in transmitting morality based on TEK-based values and cosmology. Furthermore, in our survey, we asked the students whether they were aware of traditional village groves; about one fifth of the students responded that they had heard of them. As village groves are essential components of the traditional landscape management system in Korea and provide several social and ecological functions, it is important to make people aware of the significance of village groves to conserve them. Proverbs and related folklore can be purposeful means of communicating the ecological and cultural significance of traditional landscape elements to citizens.

There is a growing recognition in South Korea of the importance of field-based learning for students. The government is exploring the formalization of a compulsory free-curriculum semester of field-based learning for middle school students in alternative learning environments including rural learning centers [45]. As public schools are exploring field-based environmental education programs for their students to spend their free-curriculum semester, ecologists and environmental educationists can avail this opportunity to incorporate the learning of TEK related proverbs and field-based observations of traditional ecological management practices within integrated learning models for enhancing the ecoliteracy of students.

Classroom learning needs to be complemented with field-based observations and experiences within traditional cultural and ecological landscapes, to help students comprehend the provenance of the TEK encapsulated in proverbs, such as by recognizing the connectivity and functional properties of social-ecological systems described in the proverbs, and ultimately appreciating the continuity of TEK. Most of the information within Korean TEK-related proverbs pertains to ecological environments that exist, and can be experienced, in rural Korean landscapes. For example, maeulsoop and bibosoop (traditional village groves) are elements of traditional Korean landscapes, where learners can observe and understand important ecosystems-related information such as social-ecological resilience, ecological limits, and community based natural resources management for enhancing local biodiversity and favorable microclimatic conditions. These traditional landscape elements are referred to in proverbs, but are rarely visible in Korean urban landscapes. Guided and purposeful field-based learning can thus adequately complement proverb-based learning [46].

Furthermore, because TEK related proverbs present factual observations, it is also relevant that learning models for enhancing ecoliteracy integrate components of socially participative or co-creative learning, such as learning through interaction with old people in rural areas where intergenerational knowledge gained from observations of ecosystems, and their transmission of this knowledge through proverbs, can be experienced first-hand. In addition, senior rural community members, who serve as living repositories of such TEK-related folklore, proverbs, and wisdom, can be involved in developing and implementing integrated learning programs for enhancing ecoliteracy among youth.

\subsection{Limitations of the Study}

Although our study provides some important implications for sustainability education, by considering TEK and folklore as part of integrated learning approaches for enhancing ecoliteracy, our scope is limited in that we focus on only two, albeit socio-ecologically predominant, natural resources: rain (water) and trees. It is possible that an analysis of other Korean traditional proverbs may deliver either different or more comprehensive aspects of TEK and ecoliteracy components.

It is seen that students find most of their knowledge of proverbs through books and formal educational curricula; this represents one of the dimensions of learning, namely the theoretical. It is necessary to further examine the efficacy of proverbs-related learning within integrated approaches for environmental learning that complement the comprehension of TEK with field-based observational and experiential learning of social and ecological systems. Such multidimensional learning approaches will allow learners to cultivate a holistic understanding of the social-cultural aspects, non-linear dynamics and uncertainties within the earth system [47,48]. Lastly, the sources of proverbs and factors in relation to ecoliteracy may vary depending on different groups of students. 


\section{Conclusions}

This study contributes two important aspects for sustainability learning: (1) it sheds light on TEK and ecoliteracy components embedded in traditional proverbs; and (2) explores the usefulness of traditional TEK related proverbs as a means of inculcating ecoliteracy in citizens.

It is worthwhile to comprehend alternative worldviews to reflect on today's mainstream paradigm of sustainability [31]. Given that traditional societies placed more emphasis on conserving rather than commodifying the limited natural resources that they depended on, it would be significant for modern societies to comprehend critically the social-ecological worldview of traditional societies. Meanwhile, much effort needs to be put into revitalizing and maintaining the wisdom of TEK. A few traditional communities have shown resilience to modern pressures to their livelihoods, by managing tight feedback relationships with their ecosystems and successfully passing on TEK [49,50], whereas most of the communities have been unable to withstand the transformative pressures of urbanization and industrialization [50]. Consequently, the number of ecologically literate members, who can identify the names, uses, and related stories of living organisms in their local ecosystems, has been decreasing [2].

In enhancing public ecoliteracy, ecologists must not only revisit their roles as integral actors within social-ecological networks [10], but also adopt tools that aid in reaching larger sections of society. By using proverbs, ecologists can better communicate with common folk about ecology and engage more broadly with non-scientists [4]. The analysis of Korean traditional proverbs shows that they can be meaningful for communicating ecological principles and natural resource management practices. Similarly, with systematic efforts, knowledge of proverbs within given social-ecological contexts can be transmitted though both the written and traditionally oral mediums to reach the youth, who are the future decision makers for sustainability. Therefore, environmental educators can use proverbs or folklore sources as a bridge for unifying traditional ecological wisdom and cultural expressions with modern scientific and systems-based learning of sustainability.

Supplementary Materials: The following are available online at www.mdpi.com/2071-1050/9/7/1182/s1.

Acknowledgments: We greatly appreciate two anonymous reviewers for their insightful and constructive comments to improve our manuscript. We thank Jongho Kim for sharing his ideas in analyzing the proverbs. This research was supported by the Basic Science Research Program through the National Research Foundation of Korea, and was funded by the Ministry of Science, ICT and Future Planning (NRF-2015R1A2A2A03007350).

Author Contributions: Dowon Lee conceived initial research ideas, and Dowon Lee and GoWoon Kim designed the experiments; Miri Nam collected the data and performed initial analyses; Wanmo Kang contributed to designing and performing supplementary survey; GoWoon Kim and Wanmo Kang synthesized and finalized qualitative and quantitative analyses; GoWoon Kim and Rahul Teku Vaswani wrote the paper.

Conflicts of Interest: The authors declare no conflict of interest. This article is a revised version of a paper presented at: the "3rd International Conference on Rainwater Harvesting and Management" held in Goseong, Gyungnam, Korea in May 2012; the "5th International Conference on Traditional Forest Knowledge and Culture in Asia" in Xi'an, China in November 2012; and a conference called "Saving Traditional Asian Forest Knowledge with Participation from Local Residents" at Miyazaki University in Miyazaki Prefecture, Japan in November 2013. The founding sponsors had no role in the design of the study; in the collection, analyses, or interpretation of data; in the writing of the manuscript, and in the decision to publish the results.

\section{References}

1. Tilbury, D. Environmental education for sustainability: Defining the new focus of environmental education in the 1990s. Environ. Educ. Res. 1995, 1, 195-212. [CrossRef]

2. Pilgrim, S.; Smith, D.; Pretty, J. A cross-regional assessment of the factors affecting ecoliteracy: Implications for policy and practice. Ecol. Appl. 2007, 17, 1742-1751. [CrossRef] [PubMed]

3. Jordan, R.; Singer, F.; Vaughan, J.; Berkowitz, A. What should every citizen know about ecology? Front. Ecol. Environ. 2009, 7, 495-500. [CrossRef]

4. Cardelús, C.; Middendorf, G. Ecological literacy: The educational foundation necessary for informed public decision making. Front. Ecol. Environ. 2013, 11, 330-331. [CrossRef]

5. McBride, B.B.; Brewer, C.A.; Berkowitz, A.R.; Borrie, W.T. Environmental literacy, ecological literacy, ecoliteracy: What do we mean and how did we get here? Ecosphere 2013, 4, 1-20. [CrossRef] 
6. Reynolds, J.A.; Lowman, M.D. Promoting ecoliteracy through research service-learning and citizen science. Front. Ecol. Environ. 2013, 11, 565-566. [CrossRef]

7. Long, T.M.; Dauer, J.T.; Kostelnik, K.M.; Momsen, J.L.; Wyse, S.A.; Speth, E.B.; Ebert-May, D. Fostering ecoliteracy through model-based instruction. Front. Ecol. Environ. 2014, 12, 138-139. [CrossRef]

8. Lowman, M. Ecoliteracy in informal science education settings. Front. Ecol. Environ. 2014, 12, 474-475. [CrossRef]

9. Lewinsohn, T.M.; Attayde, J.L.; Fonseca, C.R.; Ganade, G.; Jorge, L.R.; Kollmann, J.; Overbeck, G.E.; Prado, P.I.; Pillar, V.D.; Popp, D. Ecological literacy and beyond: Problem-based learning for future professionals. Ambio 2015, 44, 154-162. [CrossRef] [PubMed]

10. Cid, C.R.; Pouyat, R.V. Making ecology relevant to decision making: The human-centered, place-based approach. Front. Ecol. Environ. 2013, 11, 447-448. [CrossRef]

11. Langen, T.A.; Mourad, T.; Grant, B.W.; Gram, W.K.; Abraham, B.J.; Fernandez, D.S.; Carroll, M.; Nuding, A.; Balch, J.K.; Rodriguez, J.; et al. Using large public datasets in the undergraduate ecology classroom. Front. Ecol. Environ. 2014, 12, 362-363. [CrossRef]

12. Stevenson, R.D.; Klemow, K.M.; Gross, L.J. Harnessing bits and bytes to transform ecology education. Front. Ecol. Environ. 2014, 12, 306-307. [CrossRef]

13. Lam, M.E. Building ecoliteracy with traditional ecological knowledge: Do, listen, and learn. Front. Ecol. Environ. 2014, 12, 250-251. [CrossRef]

14. Berkes, F. Sacred Ecology: Traditional Ecological Knowledge and Resource Management, 2nd ed.; Routledge: New York, NY, USA, 2008.

15. Berkes, F. Traditional ecological knowledge in perspective. In Traditional Ecological Knowledge: Concepts and Cases; Inglis, J.T., Ed.; International Development Research Centre: Ottawa, ON, Canada, 1993; pp. 1-9.

16. Folke, C. Traditional knowledge in social-ecological systems. Ecol. Soc. 2004, 9, 6. [CrossRef]

17. White, G.M. In Proverbs and cultural models. In Cultural Models in Language and Thought; Cambridge University Press: Cambridge, UK, 1987; pp. 151-172.

18. Kurien, J. Traditional ecological knowledge and ecosystem sustainability: New meaning to asian coastal proverbs. Ecol. Appl. 1998, 8, S2-S5. [CrossRef]

19. Creswell, J.W.; Clark, V.L.P. Designing and Conducting Mixed Methods Research; Sage Publications: Thousand Oaks, CA, USA, 2007.

20. Lee, D. Korean Traditional Ecology; ScienceBooks: Seoul, Korea, 2004; Volume 1. (In Korean)

21. Lee, D.; Yun, S.; Sung, J.; Park, S. Korean Traditional Ecology 2; ScienceBooks: Seoul, Korea, 2008 ; Volume 2. (In Korean)

22. Han, M.; Park, J. Innovative rainwater harvesting and management in the republic of korea. In Rainwater and Urban Design 2007; Engineers Australia: Barton, Australia, 2007; pp. 329-339.

23. Lee, D.; Kim, G.; Nam, M. Traditional management practices of rainwater at various spatial scales in korea. In Proceedings of the 3rd International Conference on Rainwater Harvesting and Management, Goseong, Korea, 20-24 May 2012.

24. Kim, Y.; Han, M. Rainwater storage tank as a remedy for a local urban flood control. Water Sci. Technol. Water Supply 2008, 8, 31-36. [CrossRef]

25. Lee, J.Y.; Yang, J.S.; Han, M.; Choi, J. Comparison of the microbiological and chemical characterization of harvested rainwater and reservoir water as alternative water resources. Sci. Total Environ. 2010, 408, 896-905. [CrossRef] [PubMed]

26. Koh, I.; Kim, S.; Lee, D. Effects of bibosoop plantation on wind speed, humidity, and evaporation in a traditional agricultural landscape of korea: Field measurements and modeling. Agric. Ecosyst. Environ. 2010, 135, 294-303. [CrossRef]

27. Lee, D.; Koh, I.; Park, C.R. Ecosystem Services of Traditional Village Groves in Korea; Seoul National University Press: Seoul, Korea, 2007. (In Korean)

28. Lee, E.; Krasny, M.E. The role of social learning for social-ecological systems in korean village groves restoration. Ecol. Soc. 2015, 20, 42. [CrossRef]

29. Jeong, J. Korean Proverb Unabridged Dictionary; Taehaksa: Seoul, Korea, 2006. (In Korean)

30. Hsieh, H.F.; Shannon, S.E. Three approaches to qualitative content analysis. Qual. Health Res. 2005, 15, 1277-1288. [CrossRef] [PubMed] 
31. Houde, N. The six faces of traditional ecological knowledge: Challenges and opportunities for canadian co-management arrangements. Ecol. Soc. 2007, 12, 34. [CrossRef]

32. Nadasdy, P. The politics of TEK: Power and the "integration" of knowledge. Arcy. Anthropol. 1999, 36, 1-18.

33. Nyhus, P.J.; Tilson, R. Wildlife knowledge among migrants in southern sumatra, indonesia: Implications for conservation. Environ. Conserv. 2003, 30, 192-199. [CrossRef]

34. Ahn, C. The 24 Seasonal Divisions and the Calendar of Farmers; Sonamu: Seoul, Korea, 2011.

35. National Institute of Forest Science (NIFS). Forests and Legends in Joseon; National Institute of Forest Science: Seoul, Korea, 2011. (In Korean)

36. Kim, G.; Vaswani, R.T.; Lee, D. Social-ecological memory in an autobiographical novel: Ecoliteracy, place attachment, and identity related to the korean traditional village landscape. Ecol. Soc. 2017, 22. [CrossRef]

37. Prober, S.; O'Connor, M.; Walsh, F. Australian aboriginal peoples' seasonal knowledge: A potential basis for shared understanding in environmental management. Ecol. Soc. 2011, 16. [CrossRef]

38. Lee, D. Geomantic practices of water acquisition and management during the Chosŏn dynasty. In $P^{\prime} u n g s u$ : A Study of Geomancy in Korea; Yoon, H.K., Ed.; SUNY Press: Stony Brook, NY, USA, 2017; pp. 115-138.

39. Yu, D.J.; Anderies, J.M.; Lee, D.; Perez, I. Transformation of resource management institutions under globalization: The case of songgye community forests in south korea. Ecol. Soc. 2014, 19, 2. [CrossRef]

40. Arewa, E.O.; Dundes, A. Proverbs and the ethnography of speaking folklore. Am. Anthropol. 1964, 66, 70-85. [CrossRef]

41. Baranowski, M.D. Grandparent-adolescent relations: Beyond the nuclear family. Adolescence 1982, $17,575$.

42. Dunifon, R.; Bajracharya, A. The role of grandparents in the lives of youth. J. Fam. Issue. 2012, 33, 1168-1194. [CrossRef] [PubMed]

43. Barranti, C.C.R. The grandparent/grandchild relationship: Family resource in an era of voluntary bonds. Fam. Relat. 1985, 34, 343-352. [CrossRef]

44. Berkes, F.; Kislalioglu, M.; Folke, C.; Gadgil, M. Exploring the basic ecological unit: Ecosystem-like concepts in traditional societies. Ecosystems 1998, 1, 409-415. [CrossRef]

45. So, K.; Kang, J. Curriculum reform in korea: Issues and challenges for twenty-first century learning. Asia Pac. Educ. Res. 2014, 23, 795-803. [CrossRef]

46. Ben-zvi-Assarf, O.; Orion, N. A study of junior high students' perceptions of the water cycle. J. Geosci. Educ. 2005, 53, 366-373. [CrossRef]

47. Assaraf, O.B.Z.; Orion, N. Development of system thinking skills in the context of earth system education. J. Res. Sci. Teach. 2005, 42, 518-560. [CrossRef]

48. Folke, C. Resilience: The emergence of a perspective for social-ecological systems analyses. Glob. Environ. Chang. 2006, 16, 253-267. [CrossRef]

49. Mazzocchi, F. Western science and traditional knowledge: Despite their variations, different forms of knowledge can learn from each other. EMBO Rep. 2006, 7, 463-466. [CrossRef] [PubMed]

50. Gómez-Baggethun, E.; Corbera, E.; Reyes-Garcl̄a, V. Traditional ecological knowledge and global environmental change: Research findings and policy implications. Ecol. Soc. 2013, 18. [CrossRef] [PubMed]

(C) 2017 by the authors. Licensee MDPI, Basel, Switzerland. This article is an open access article distributed under the terms and conditions of the Creative Commons Attribution (CC BY) license (http:/ / creativecommons.org/licenses/by/4.0/). 